\title{
Beta-fibrinogen (-455 G/A) and Integrin beta-3 (PLA1/A2) polymorphisms and recurrent pregnancy loss in Gaza strip-Palestine
}

\author{
Manal G. Al-Astal, Fadel A. Sharif*
}

Department of Medical Laboratory Sciences, Islamic University of Gaza, Gaza, Palestine

Received: 6 January 2014

Accepted: 2 February 2014

\author{
*Correspondence: \\ Dr. Fadel A. Sharif, \\ E-mail: fsharif@iugaza.edu.ps
}

(C) 2014 Al-Astal MG et al. This is an open-access article distributed under the terms of the Creative Commons Attribution Non-Commercial License, which permits unrestricted non-commercial use, distribution, and reproduction in any medium, provided the original work is properly cited.

\begin{abstract}
Background: This study was conducted in order to determine the relationship between the common polymorphisms in $\beta$-fibrinogen -455 G/A (rs1800790) and Integrin beta-3 T196C (PLA1/A2, rs5918) and recurrent pregnancy loss (RPL) in a group of Palestinian women residing in Gaza strip.

Methods: The study presented here is a retrospective association study with a case-control design. The study population consisted of 102 women who suffered from RPL and 97 healthy women matched for age and without a previous history of RPL. DNA extracted from blood samples of all subjects was investigated for the $\beta$-fibrinogen ($455 G>A$ ) and Integrin beta-3 (PLA1/A2) polymorphisms using PCR-RFLP and PCR-SSP, respectively.

Results: The study revealed that $\beta$-fibrinogen $-455 \mathrm{G} / \mathrm{A}$ minor allele frequency (allele A) and its homozygous genotype (AA) were not significantly different between the RPL and the control groups. Likewise, there was no significant difference in the distribution of the ITGB-3 variant allele (PLA2) or PLA2/A2 genotype between the two groups. $\beta$-fibrinogen AA genotype was evident in $3.9 \%$ of the patients and in $4.1 \%$ of the controls $(\mathrm{P}$-value $=0.94)$. The frequency of PLA2/A2 was observed in $2.0 \%$ of the patients and in $2.1 \%$ of the controls $(\mathrm{P}$-value $=0.96)$.

Conclusion: Results of the present study indicate that there is no significant association between the $\beta$-fibrinogen (455 G>A) or Integrin beta-3 (PLA1/A2) common polymorphisms and the occurrence of RPL in Gaza strip. This nonsignificant relation indicates that the investigated polymorphisms do not constitute a tangible risk for RPL in our population. Therefore, it is not recommended to consider these two polymorphisms when screening for inherited thrombophilia in Gaza strip.
\end{abstract}

Keywords: $\beta$-fibrinogen, Integrin beta-3, gene polymorphism, RPL, Gaza Strip, Palestine

\section{INTRODUCTION}

Recurrent pregnancy loss (RPL) is defined as the occurrence of $\geq 2$ consecutive pregnancy losses before 20 th week of gestation. This stressful problem is encountered in about $2 \%$ of women attempting pregnancy. Known causes of RPL include autoimmune disorders ( 20\%), endocrine factors $(17-20 \%)$, anatomic abnormalities (10-15\%), genetic abnormalities (2-5\%) and infectious factors (0.5$5 \%$ ). In an ample number of cases, mounting to $40-50 \%$, however, the causes remain indefinite (Abu-Asab et al., 2011; Lavigne et al., 2005; Ford and Schust, 2009).

In the last two decades, heritable and/or acquired thrombophilias have strongly emerged as a possible etiology for RPL. Thrombophilia can be defined as a 
predisposition to form thrombi inappropriately. Marked thrombocytosis, increased platelet aggregation, increased activity levels of coagulation factors, and excess plasma levels of fibrinolytic inhibitors may all enhance thrombosis.

Fibrinogen (Factor I) is a glycoprotein that participates in the coagulation cascade. Fibrinogen is composed of three pairs of polypeptide chains (named $\alpha, \beta$ and $\gamma$ ) linked by disulfide bonds. Mutations in $\beta$-fibrinogen gene lead to thrombotic tendency. The fibrinogen-raising betafibrinogen gene $-455 \mathrm{G} / \mathrm{A}$ polymorphism may enhance the physiological increase in fibrinogen levels during pregnancy and thereby may predispose to obstetric complications (Leander et al., 2002).

Human platelets carry membrane glycoproteins that control platelet aggregation and activation. A number of clinical studies have suggested that certain polymorphisms of genes encoding these proteins increase the risk for thrombosis (Chiras et al., 2009). Human platelet antigen-1 "HPA-1", GpIIIa or Integrin Beta-3 is a platelet membrane glycoprotein encoded by ITGB3 gene. The common polymorphism T196C in this gene results in a L59P substitution and is described as the PLA1/A2 alloantigen system (Chiras et al., 2009; Tan et al., 2012).

Studies on prevalence of beta-fibrinogen -455G/A polymorphism among patients with RPL in different populations have yielded conflicting results, whereas some investigators showed an association between this polymorphism and RPL (Goodman et al., 2006; Ticconi et al., 2011; Jeddi-Tehrani et al., 2011; Torabi et al., 2012) others, however, reported the lack of a meaningful association (e.g., Pihusch et al., 2001; Coulam et al., 2006; Yenicesu et al., 2010; Ozdemir et al., 2011)

The trend is not different for ITGB3 PLAl/A2 polymorphism as some authors stated that this polymorphism constitute a risk factor for RPL (Ruzzi et al., 2005; Ivanov et al., 2010; Lambrinoudaki et al., 2010; Yenicesu et al., 2010; Goncharova et al., 2013), other studies did not confirm such a relation (Pihusch et al., 2001; Ozdemir et al., 2011).

This study was performed in order to investigate the relation between RPL and the common polymorphisms in $\beta$-fibrinogen (-455 G>A; "rs1800790") and Integrin beta3 a/b (PLA1/A2; "rs5918") genes among Palestinian RPL women residing in Gaza Strip.

\section{METHODS}

\section{Study population}

The study was conducted on 102 Palestinian women, 1835 years old, from Gaza strip who had at least two RPLs $\leq 20$ weeks of gestation. Age and ethnicity matched 97 women with at least two live births and without a previous history of abortion or pregnancy-associated complications served as the control group. Informed consent was obtained from all participants, and approval for conducting the study was obtained from the local ethics committee.

\section{DNA extraction and polymorphism determination}

Genomic DNA was extracted from EDTA-blood samples using Wizard Genomic DNA purification Kit (Promega, USA) following the manufacturer's instructions. Genotyping was performed using polymerase chain reaction (PCR) and restriction length fragment polymorphism (RLFP) for $\beta$-fibrinogen - 455G>A and sequence-specific (PCR-SSP) for ITGB3 PLA1/A2.

The PCR primers (Table I), restriction enzyme and PCR conditions employed in genotyping $\beta$-fibrinogen $455 \mathrm{G}>\mathrm{A}$ were carried out as described by Xiang-feng et al. (2008). The polymorphism was defined by digesting the PCR product with the restriction endonuclease HaeIII (New England BioLabs) at $37^{\circ} \mathrm{C}$ for $16 \mathrm{hrs}$. The polymorphic A allele PCR product remains uncut (336bp) whereas, the wild type $G$ allele is cut into two fragments of 215 and 121-bp.

The ITGB3 PLA1/A2 polymorphism was determined by PCR-SSP as described by Chiras et al. (2009) using the primers shown in Table 2 .

\section{Statistical analysis}

The Hardy-Weinberg equilibrium (HWE) equation was used to calculate the expected genotypes frequencies. Difference between expected and observed genotypes was assessed by Chi square $\left(\mathrm{X}^{2}\right)$ test. $P$-values less than 0.05 were considered statistically significant. The frequencies of the alleles and genotypes were compared between patient and control groups by $\mathrm{X}^{2}$ test. The odds ratio (OR) and 95\% confidence interval (CI) were also estimated in order to test the relation between RPL and the investigated polymorphisms.

\section{RESULTS}

\section{$-455 G>A$ fibrinogen gene polymorphism and RPL}

Genotype and allele frequencies of $-455 \mathrm{G}>\mathrm{A}$ fibrinogen gene polymorphism were not significantly different between RPL patients and controls (Table 3). Moreover, statistical analyses of the genotypes under both recessive and dominant models (data no shown) revealed no significant difference between the two study groups.

\section{PLA1/A2 ITGB3 gene polymorphism and RPL}

Genotype and allele frequencies of PLA1/A2 ITGB3 gene polymorphism were not significantly different between RPL patients and controls (Table 4). Additionally, statistical analyses of the genotypes under both recessive and dominant models (data not shown) indicated no significant difference between RPL and control groups. 
Table 1: Primer sequences and restriction enzyme for $-\mathbf{4 5 5 G}>\mathrm{A}$ fibrinogen.

\begin{tabular}{|c|c|c|c|}
\hline Primer sequences & PCR products & $\begin{array}{l}\text { Restriction } \\
\text { enzyme }\end{array}$ & Digested products \\
\hline $\begin{array}{l}\text { F: 5'-AGGGTCTTTCTGATGTGT-3, } \\
\text { R: 5'-AAGTTAGGGCACTCCTCA-3, }\end{array}$ & $336 \mathrm{bp}$ & HaeIII & $\begin{array}{l}\text { A allele } 336 \mathrm{bp} \\
\mathrm{G} \text { allele } 215+121 \mathrm{bp}\end{array}$ \\
\hline
\end{tabular}

Table 2: Primers and lengths of PCR products for ITGB3 PLA1/A2 polymorphism.

\begin{tabular}{|lll|}
\hline Primer sequence & \multicolumn{1}{c|}{$\begin{array}{c}\text { PCR products } \\
\text { size (bp) }\end{array}$} \\
\hline Common forward & 5' GGAGGTAGAGAGTCGCCATAG 3' & \\
\hline $\boldsymbol{P L A 1}$ specific reverse primer & 5' TCACAGCGAGGTGAGGCCA 3' & 90 \\
\hline $\boldsymbol{P L A 2}$ specific reverse primer & 5' TCACAGCGAGGTGAGGCCG 3' & 90 \\
\hline
\end{tabular}

Table 3: Frequency of the -455G>A fibrinogen gene polymorphism among RPL patients and control subjects.

\begin{tabular}{|c|c|c|c|c|c|}
\hline Polymorphism & Genotype/Allele & $\begin{array}{l}\text { RPL } \\
(\mathrm{N}=102)\end{array}$ & $\begin{array}{l}\text { Control } \\
(\mathrm{N}=97)\end{array}$ & Odds Ratio (95\% CI) & P-value \\
\hline \multirow{4}{*}{$\begin{array}{l}\text { fibrinogen } \\
-455 \mathrm{G}>\mathrm{A}\end{array}$} & GG & $70(68.6 \%)$ & $62(63.9 \%)$ & $1.23(0.69-2.22)$ & 0.48 \\
\hline & GA & $28(27.5 \%)$ & $31(32.0 \%)$ & $0.81(0.44-1.48)$ & 0.49 \\
\hline & $\mathbf{A A}$ & $4(3.9 \%)$ & $4(4.1 \%)$ & $0.95(0.23-3.91)$ & 0.94 \\
\hline & $\begin{array}{l}\text { G allele } \\
\text { A allele }\end{array}$ & $\begin{array}{l}168(82.4 \%) \\
36(17.6 \%)\end{array}$ & $\begin{array}{l}155(79.9 \%) \\
39(20.1 \%)\end{array}$ & $0.85(0.52-1.41)$ & 0.53 \\
\hline
\end{tabular}

Table 4: Frequency of the PLA1/A2 ITGB3 gene polymorphism among RPL patients and control subjects.

\begin{tabular}{|c|c|c|c|c|c|}
\hline Polymorphism & $\begin{array}{l}\text { Genotype/ } \\
\text { Allele }\end{array}$ & $\begin{array}{l}\text { RPL } \\
(\mathrm{N}=102)\end{array}$ & $\begin{array}{l}\text { Control } \\
(\mathrm{N}=97)\end{array}$ & $\begin{array}{l}\text { Odds Ratio } \\
(95 \% \text { CI })\end{array}$ & P-value \\
\hline \multirow{4}{*}{$\begin{array}{l}\text { ITGB3 } \\
\text { PLA1/A2 }\end{array}$} & $\mathrm{A} 1 / \mathrm{A} 1$ & $70(68.6 \%)$ & $62(63.9 \%)$ & $1.23(0.68-2.22)$ & 0.48 \\
\hline & A1/A2 & $30(29.4 \%)$ & $33(34.0 \%)$ & $0.81(0.44-1.47)$ & 0.48 \\
\hline & A2/A2 & $2(2.0 \%)$ & $2(2.1 \%)$ & $0.95(0.13-6.88)$ & 0.96 \\
\hline & $\begin{array}{l}\text { A1 allele } \\
\text { A2 allele }\end{array}$ & $\begin{array}{l}170(83.3 \%) \\
34(16.6 \%)\end{array}$ & $\begin{array}{l}157(81 \%) \\
37(19 \%)\end{array}$ & $1.18(0.71-1.97)$ & 0.53 \\
\hline
\end{tabular}

\section{Hardy-Weinberg equilibrium}

Analysis of the observed and the calculated expected genotype frequencies of $\beta$-fibrinogen $455 \mathrm{G}>\mathrm{A}$ and ITGB3 PLA1/A2 polymorphisms in the control group showed that the distribution of both genes' genotypes are in Hardy-Weinberg equilibrium.

\section{DISCUSSION}

Normal pregnancy is inherently a hypercoagulable state where it is associated with an increase in various physiologic coagulants and a decrease in natural anticoagulants (Brenner et al., 2006; Cernecab et al.,
1997). Genetic variation in any of the several loci involved in the coagulation/fibrinolysis system may further exacerbate this hypercoagulability and result in intervillous or spiral-artery thrombosis, inadequate placental perfusion and could lead to miscarriage (Ford and Schust, 2009). This theory is solidified by the fact that many thrombophilia-associated RPL cases have been successfully treated with administering appropriate anticoagulants (Gris et al., 2004; Brenner et al., 2005).

$\beta$-fibrinogen and ITGB3 proteins are components of the coagulation system and common polymorphisms in the genes (-455G/A and PLA1/A2, respectively) encoding those proteins have been linked with thrombophilia and 
increased risk of RPL (Goodman et al., 2006; Ticconi et al., 2011; Jeddi-Tehrani et al., 2011; Torabi et al., 2012; Ruzzi et al., 2005; Ivanov et al., 2010; Lambrinoudaki et al., 2010; Yenicesu et al., 2010; Goncharova et al., 2013). Our findings, however, did not replicate this association and revealed that these two polymorphisms do not represent a risk factor for RPL in our population. Meanwhile, results of the present study are in agreement with other reports that also showed lack of association between RPL and -455G/A and PLA1/A2 (Pihusch et al., 2001; Coulam et al., 2006; Yenicesu et al., 2010; Ozdemir et al., 2011).

Discrepancy between results of association studies conducted on various populations could be due to many reasons including study sample characteristics, population genetic variation(s) unrelated to investigated polymorphism(s), presence of nucleotide polymorphism somewhere else in, or in the vicinity of, the investigated loci, epigenetic alterations and linkage disequilibrium to other sequence variants.

Some authors, due to the multifactorial nature of at least $40-50 \%$ the RPL cases, proposed that thrombophilia risk alleles should not be tested individually but as part of a panel of multiple gene variants (Coulam et al., 2006; Goodman et al., 2006; Torabi et al., 2012; ). Despite our agreement on that proposition we still believe that each allele in this panel, when tested alone, should show significant difference between RPL patients and control subjects. Furthermore, no international consensus will be attained on the component polymorphisms of such a panel and perhaps each population will have its own particular panel.

In light of the obtained results we do not recommend inclusion of $\beta$-fibrinogen $-455 \mathrm{G} / \mathrm{A}$ and ITGB3 PLA1/A2 polymorphisms when screening idiopathic RPL cases for inherited thrombophilia in our population.

Funding: This work was supported by the Scientific Research Council [Scientific Research Grant 20142015], Ministry of Education and Higher Education, State of Palestine

Conflict of interest: None declared

Ethical approval: The study was approved by the Local Ethics Committee

\section{REFERENCES}

1. Abu-Asab NS, Ayesh SK, Ateeq RO, Nassar SM, EL-Sharif WA. Association of Inherited Thrombophilia with Recurrent Pregnancy Loss in Palestinian Women. Obstetrics and Gynecology International 2011; Article ID 689684, 6 pages doi:10.1155/2011/689684.

2. Brenner B, Hoffman R, Carp H, Dulitsky M, Younis J. Efficacy and safety of two doses of enoxaparin in women with thrombophilia and recurrent pregnancy loss: the LIVE-ENOX study. J. Thrombosis and Haemostasis 2005; 3(2):227-229.

3. Brenner B. Thrombophilia and adverse pregnancy outcome. Obstet Gynecol Clin North Am 2006;33:443-456.

4. Cernecab F, Ricci G, Simeoneb R, Malisanoa M, Albericoa S, Guaschinoa S. Coagulation and fibrinolysis changes in normal pregnancy. Increased levels of procoagulants and reduced levels of inhibitors during pregnancy induce a hypercoagulable state, combined with a reactive fibrinolysis. Eur J Obstet Gynecol Reprod Biol. 1997; 73(1):31-33.

5. Chiras T, Papadakis ED, Katopodi A, Chatzianesti E, Fourtounas K, Papakonstantinou S, Theodoropoulos I, Dakouras A, Zerefos N, Valis D, Exarchou HT. Platelet GP IIIA Polymorphism HPA-1 (PLA1/2) Is Associated with Hypertension as the Primary Cause for End-stage Renal Disease in Hemodialysis Patients from Greece. In Vivo. 2009; 23:177-182.

6. Coulam CB, Jeyendran RS, Fishel LA, Roussev R. Multiple thrombophilic gene mutations rather than specific gene mutations are risk factors for recurrent miscarriage. Am J Reprod Immunol. 2006; 55:360368.

7. Ford HB, Schust DJ. Recurrent Pregnancy Loss. Etiology, Diagnosis, and Therapy. Reviews in Obstetrics and Gynecology 2009; 2:76-83.

8. Goncharovaa I, Babushkinaa O, Minaychevaa L, Markovaa V, Kulisha E, Salakhovb R, Makeevaa O, Puzyreva V. Prevalence of Alleles of Polymorphic Variants Leu33Pro and Leu66Arg Gene ITGB3 among Inhabitants of Siberia. Russian Journal of Genetics. 2013;49:877-880.

9. Goodman CS, Coulam CB, Jeyendran RS, Acosta VA, Roumen R. Which thrombophilic gene mutations are risk factors for recurrent pregnancy loss? Am J Reprod Immunol.2006;56:230-236.

10. Ivanov PD, Komsa-Penkove RS, Konova EI, Tsvyatkovska TM, Kovacheva, Simeonova MN, Tanchev SY. Polymorphism A1/A2 in the cell surface integrin subunit $\beta 3$ and disturbance of implantation and placentation in women with recurrent pregnancy loss. Fetil Steril 2010; 94(7):2843-2845.

11. Jeddi-Tehrani M, Torabi R, Zarnani AH, Mohammadzadeh A, Arefi S, Zeraati H, Akhondi MM, Chamani-Tabris L, Idali F, Emami S, Zarei S. Analysis of plasminogen activator inhibitor-1, integrin beta3, beta fibrinogen, and methylenetetrahydrofolate reductase polymorphisms in Iranian women with recurrent pregnancy loss. Am J Reprod Immunol 2011; 66(2):149-156.

12. Lambrinoudaki I, Armeni E, Kaparos GJ, Christodoulakos GE, Sergentanis TN, Alexandrou A, Creatsa M, Kouskouni E. The frequency of early, spontaneous miscarriage associated with the leu33pro polymorphism of Glycoprotein IIIa: A pilot study. Australian and New Zealand Journal of Obstetrics and Gynaecology 2010; 50(5):485-490.

13. Lavigne GL, Nouvellon EC, Mercier E, Quere I, Dauzat M, Mares P, Gris JC. The association 
between hereditary thrombophilias and pregnancy loss. Haematologica. 2005;90:1223-1230.

14. Leander R, Wiman B, Hallqvist J, Falk G, De Faire $\mathrm{U}$. The G-455A polymorphism of the fibrinogen $\mathrm{Bb}-$ gene relates to plasma fibrinogen in male cases, but does not interact with environmental factors in causing myocardial infarction in either men or women. Journal of Internal Medicine.2002; 252: 332-341.

15. Ozdemir O, Yenicesu G I, Silan F, Köksal B, Atik S, Ozen F, Göl M, Cetin A. Recurrent pregnancy loss and its relation to combined parental thrombophilic gene mutations. Genet Test Mol Biomarkers.2012;16:279-286.

16. Pihusch R, Buchholz T, Lohse $\mathrm{P}$, Rübsamen $\mathrm{H}$, Rogenhofer N, Hasbargen U, Hiller E, Thaler CJ. Thrombophilic gene mutations and recurrent spontaneous abortion: prothrombin mutation increases the risk in the first trimester. Am J Reprod Immunol. 2001;46:124-131.

17. Ruzzi L, Ciarafoni I, Silvestri L, Semeraro ML, Abeni D. Association of PLA2 polymorphism of the ITGB3 gene with early fetal loss. Fertil Steril 2000; 83(2):511-512.

18. Tan J, Lian LH, Nadarajan VS: Genetic polymorphisms of human platelet antigens-1 to -6 , and -15 in the Malaysian population. Blood Transfus. 2012;10:368-376.

19. Ticconi C, Mancinelli F, Gravina P, Federici G, Piccione E, Bernardini S. Beta-fibrinogen G-455A polymorphisms and recurrent miscarriage. Gyecol Obstet Invest 2011;71(3):198-201.

20. Torabi R, Zarei S, Zeraati H, Zarnani A, Akhondi M, Hadavi R, Shiraz E, Jeddi-Tehrani M. Combination of Thrombophilic Gene Polymorphisms as a Cause of Increased the Risk of Recurrent Pregnancy Loss. J Reprod Infertil. 2012;13:89-94.

21. Xiang-feng L, Hong-jiang Y, Xiao-yang Z, Laiyuan W, Jian-feng H, Dong-feng G. Influence of fibrinogen $\beta$-chain gene variations on risk of myocardial infarction in a Chinese Han population. Chinese Medical Journal 2008; 121(16):1549-1553.

22. Yenicesu G I, Cetin M, Ozdemir O, Cetin A, Ozen F, Yenicesu C, Yildiz C, Nadir K. A Prospective Case-Control Study Analyzes 12 Thrombophilic Gene Mutations in Turkish Couples with Recurrent Pregnancy Loss. Am J Reprod Immunol. 2010; 63:126-136.

DOI: $10.5455 / 2320-1770$. ijrcog20140326

Cite this article as: Al-Astal MG, Sharif FA. Betafibrinogen (-455 G/A) and Integrin beta-3 (PLA1/A2) polymorphisms and recurrent pregnancy loss in Gaza strip-Palestine. Int J Reprod Contracept Obstet Gynecol 2014;3:134-8. 